\title{
Thermodynamic reasons of agglomeration of dust particles in the thermal dusty plasma
}

\author{
V.I.Vishnyakov, G.S.Dragan \\ Department of Physics, Odessa National University, \\ 65026 Odessa, Ukraine
}

Received July 21, 2003

\begin{abstract}
The thermodynamic equilibrium of thermal dusty plasmas consisting of ionized gas (plasma) and solid particles (dust grains), which interact with each other, is studied. The tendency of grains in dusty plasmas to agglomerate corresponds to the tendency of dusty plasmas to balanced states. When grains agglomerate, electrical perturbations generated by each grain concentrate inside the agglomerate. The plasma is perturbed only by the agglomerate's exterior surface. The greater number of possible states for electrons and ions in plasma depends on the volume of perturbation of grains. The fewer are the perturbations the greater is the amount of possible states for electrons and ions in plasma. If the grains collected from a distance smaller than 8 Debye lengths, the total volume of perturbations is minimized; the free energy of the plasma is also minimized.
\end{abstract}

Key words: plasma, agglomerate, thermodynamics, perturbation

PACS: 52.27.L, 52.25.K

Dusty plasma represents the plasma, which contains typically submicron-size particles (grains). Following the discovery in gas-discharge plasma of ordered structures named plasma crystals $[1,2]$, interest in these objects grew considerably. Ordered structures of grains were observed not only in gas-discharge plasma, but also as products of combustion [3]. Shukla [4] notes that the physics of dusty plasma is one of the most rapidly growing fields of science, because interfacial interaction in the dusty plasma has not been sufficiently investigated. Dust grains in plasmas interact with plasma and with each other as in the gas-discharge plasma [5] and in the thermal plasma $[3,6]$.

The combustion plasma is one of the most difficult types of dusty plasmas [7] since many different nonequilibrium processes occur in it, such as chemical reactions in a gas phase and on the surface of grains, transpiration and condensation, agglomeration of particles. But within the band of products of combustion [8] it is possible to find the local thermodynamic equilibrium area in which the gas phase 


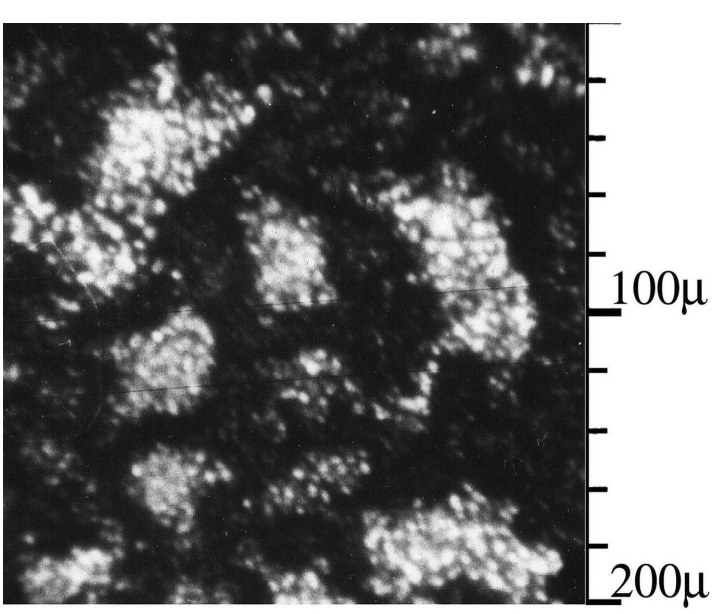

a

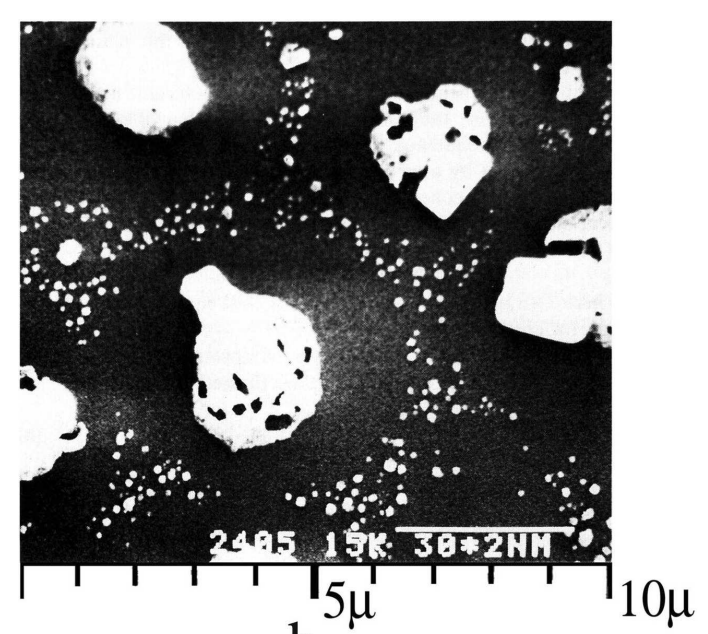

b

Figure 1. The photomicrographs of samples taken from the plasma of combustion: (a) an optical microscope, (b) an electron microscope.

represents low-temperature plasma, and the condensed phase - fluid or solid grain of metal oxides, black carbon and other dust particles. The distribution grain size, as a rule, has two maximums, and in some cases three [3]. One of the maximums match the micron size grains which are agglomerates of smaller dust particles. The medial maximum, if any, is represented by the dust grains of the size of some tenths of a micron that often are an agglomerate of smaller dust particles. The latter is the result of volumetric condensation of metal oxides. The grain charge in these systems varies from unities of elementary charge for dust with radius about $1 \mathrm{~nm}$ up to hundreds of elementary charges for grains of the micron size.

The photomicrographs of samples taken from the combustion plasma with the dust grains of aluminum and silicon are shown in figure 1 .

We try to prove that the attraction of grains corresponds to the tendency of plasmas to thermodynamic equilibrium.

Suppose, plasma consists of unionizable buffer gas and an addition of easily ionizable atoms, ions and electrons, and monodisperse spherical grains with the radius of $r_{\mathrm{g}}$ are located in it. The temperatures of electrons, ions and dust grains are equal $T$ (we shall use a Kelvin temperature). The potential distribution in the neighborhood of a grain is described by a nonlinear Poisson equation $[9,10]$

$$
\frac{1}{r^{2}} \frac{\mathrm{d}}{\mathrm{d} r}\left[r^{2} \frac{\mathrm{d} \phi(r)}{\mathrm{d} r}\right]=-4 \pi \rho(r)=8 \pi e n_{0} \sinh \frac{e \phi(r)}{k_{\mathrm{B}} T}
$$

where $n_{0}$ is the electron and ion number densities in the area where $\phi=0, k_{\mathrm{B}}$ is the Boltzmann constant.

Detailed examination $[11,12]$ of this equation reveals that dust grains in plasma are strongly screened because an electrical perturbation caused by a grain charge completely concentrates in the space-charge sheath with the width of less than $4 D$ from the grain surface (where the Debye screening length is $D=\sqrt{k_{\mathrm{B}} T / 8 \pi e^{2} n_{0}}$ ). 
It is caused by the potential at the distance of $4 D$ being diminished from infinitely large value up to the value of $0.1 k_{\mathrm{B}} T$ for large grains. This distance decreases with diminution of grain radius [13]. Hence, one grain causes perturbation in the volume of plasma with the maximum characteristic radius $r_{\mathrm{g}}+4 D$.

Outside the space-charge sheath whose maximal size is $4 D$, ionization equilibrium in the unperturbed plasma is featured by Saha equation [9] $n_{\mathrm{e}} n_{\mathrm{i}}=n_{\mathrm{a}} K_{\mathrm{s}}(T)$; where $n_{\mathrm{e}}, n_{\mathrm{i}}$ and $n_{\mathrm{a}}$ are the electron, ion and atom number densities; $K_{\mathrm{s}}(T)=$ $2\left(g_{\mathrm{i}} / g_{\mathrm{a}}\right)\left(m_{\mathrm{e}} k_{\mathrm{B}} T / 2 \pi \hbar^{2}\right)^{3 / 2} \exp \left(-I / k_{\mathrm{B}} T\right) ; g_{\mathrm{i}} / g_{\mathrm{a}}$ is the ratio of internal statistical sums of ion and atom, and $I$ is the atomic ionization potential.

Inside the sheath near the surface of dust grain, the electric field ensures not only the balance upset between ion and electron densities but also the infringement of ionization equilibrium. In this case the ionization degree is defined by the equation $n_{\mathrm{e}} n_{\mathrm{i}}=n_{\mathrm{a}} K_{\mathrm{s}}(T) \exp \left(\psi / k_{\mathrm{B}} T\right)$, where the value of parameter $\psi$ depends on the processes occurring near the grain surface $[6,8]$. Therefore, the properties of plasma inside the sheath can strongly differ from the properties of the unperturbed plasma. This perturbation area of plasmas including a grain and plasma particles can be introduced as a volume of perturbation generated by one grain.

Thus, a total volume of perturbation that is generated by all free grains (not agglomerate) in plasma is as follows:

$$
V_{\mathrm{g}}=4 / 3 \pi\left(r_{\mathrm{g}}+4 D\right)^{3} N_{\mathrm{g}},
$$

where $N_{\mathrm{g}}$ is the number of grains; we neglect the coefficient of bulk weight $\pi / \sqrt{18}$.

When the grains agglomerate, electrical perturbations generated by each grain are concentrated inside the agglomerate. The plasma is perturbed only by the agglomerate's exterior surface. Therefore, the characteristic volume of agglomerate's perturbation equals to

$$
V_{\mathrm{ag}}(x)=4 / 3 \pi\left[\left(r_{\mathrm{g}}+x\right) N_{\mathrm{g}}^{1 / 3}+4 D\right]^{3},
$$

where $x$ is half the distance between the surfaces of grains.

From equations (1) and (2) it follows that the grains combined into an agglomerate cause a perturbation in a smaller volume of plasma than when they are in a free state.

Helmholts free energy of plasmas depends on the total volume of perturbations caused by grains. The fewer are the perturbations caused by the grains the greater is the number of possible states for electrons and ions in plasma. If the grains approach each other at the distance smaller than $8 \mathrm{D}$, the total volume of perturbations is minimized. Hence, the free energy of the plasma is also minimized.

Let us consider the plasma in the ideal gas approach. The free energy of plasma components is $[14]$

$$
F_{j}=-N_{j} k_{\mathrm{B}} T\left(1+\ln \frac{V}{N_{j} V_{Q j}}\right),
$$

where $N_{j}$ is the number of particle species $j$ ( $j$ equals $e$ for the electrons, $i$ for single charge ions, and $a$ for the easily ionizable atoms), $V$ is the volume of the system, $V_{Q j}=\left(2 \pi \hbar^{2} / m_{j} k_{\mathrm{B}} T\right)^{3 / 2}$ is the quantum volume of component $j$. 
Ionization degree in low-temperature plasma is so small that we can neglect the ion and electron parts of the total free energy of the plasma, because $N_{\mathrm{a}} \cong N_{\mathrm{A}}$, where the number of easily ionizable addition agent $N_{\mathrm{A}}=N_{\mathrm{i}}+N_{\mathrm{a}}$ is constant (for example in plasma with kalium atom number density $10^{21} \mathrm{~m}^{-3}$ and $T=2300 \mathrm{~K}$ Saha equation gives electron and ion number densities $10^{19} \mathrm{~m}^{-3}$ ). We also neglect the change of the volume of the sheath due to their overlapping in agglomerate since in real systems the total volume of the sheath is much smaller than the volume of the unperturbed plasma.

The unperturbed plasma occupies the volume $V-V_{\mathrm{ag}}(x)$ when dust grains are agglomerate. Dependence of a free energy of the plasma on the volume of perturbations (i.e. size of agglomerate) can be presented as follows:

$$
F_{\mathrm{pl}}(x)=-N_{\mathrm{A}} k_{\mathrm{B}} T\left[1+\ln \frac{V-V_{\mathrm{ag}}(x)}{N_{\mathrm{A}} V_{Q a}}\right] \cong F_{\mathrm{pl}}^{0}+N_{\mathrm{A}} k_{\mathrm{B}} T \frac{V_{\mathrm{ag}}(x)}{V} .
$$

Here $F_{\mathrm{pl}}^{0}$ is the free energy of the plasma in volume $V$ without grains equation (3), and we take into account that $V \gg V_{\text {ag }}$.

The free energy of the system of dust grains with perturbations in the ideal gas approach is as follows:

$$
F_{\mathrm{g}}=-N_{\mathrm{g}} k_{\mathrm{B}} T\left[1+\ln \frac{4 \pi\left(r_{\mathrm{g}}+x\right)^{3}}{3 N_{\mathrm{g}} V_{\mathrm{Qg}}}\right]=F_{\mathrm{g}}^{0}-N_{\mathrm{g}} k_{\mathrm{B}} T \ln \frac{4 \pi\left(r_{\mathrm{g}}+x\right)^{3}}{3 V}
$$

where $F_{\mathrm{g}}^{0}$ is the free energy of the dust grains system in volume $V$ without plasma.

The free energy of a subsystem of dust grains depends not only on the volume they occupy but also on the interaction of the grains with each other $U(x)$. Thus,

$$
F_{\mathrm{g}}(x)=F_{\mathrm{g}}^{0}-N_{\mathrm{g}} k_{\mathrm{B}} T \ln \frac{4 \pi\left(r_{\mathrm{g}}+x\right)^{3}}{3 V}+N_{\mathrm{g}} U(x) .
$$

Electrostatic energy of the grains in the agglomerate is determined by the action of electrical forces, which is necessary for the relocation of the grains from an existing configuration (when the distance is smaller than $2 \times 4 D$ ) to the distance of $2 \times 4 D$, since at the distance of more than $2 \times 4 D$ between the surfaces the grains do not interact. This is equivalent to the grains being evenly distributed throughout the volume $(E(4 D) \cong 0)$.

The computer modelling proves that it is enough to take into account the effect of 12 proximate neighbors,

$$
U(x)=12 Q_{\mathrm{g}} \int_{r_{\mathrm{g}}+x}^{r_{\mathrm{g}}+4 D} E(r) \mathrm{d} r \cong 12 Q_{\mathrm{g}} \frac{\phi_{\mathrm{g}} r_{\mathrm{g}}}{r_{\mathrm{g}}+x} \exp \frac{-x}{D},
$$

where $Q_{\mathrm{g}}$ is the grain's charge, $\phi_{\mathrm{g}}$ is the surface potential (which is usually the tenths of a volt).

We are interested only in the variable part of the free energy depending on $x$. Therefore, we neglect the constants $F_{\mathrm{pl}}^{0}$ and $F_{\mathrm{g}}^{0}$. The resulting dependence of free 
energy on the distance existing between the grains is the sum of equations (4) and (5) without constants,

$$
\Delta F \approx N_{\mathrm{A}} k_{\mathrm{B}} T\left(\frac{V_{\mathrm{ag}}(x)}{V}\right)-N_{\mathrm{g}} k_{\mathrm{B}} T \ln \frac{4 \pi\left(r_{\mathrm{g}}+x\right)^{3}}{3 V}+12 N_{\mathrm{g}} Q_{\mathrm{g}} \frac{\phi_{\mathrm{g}} r_{\mathrm{g}}}{r_{\mathrm{g}}+x} \exp \frac{-x}{D}
$$

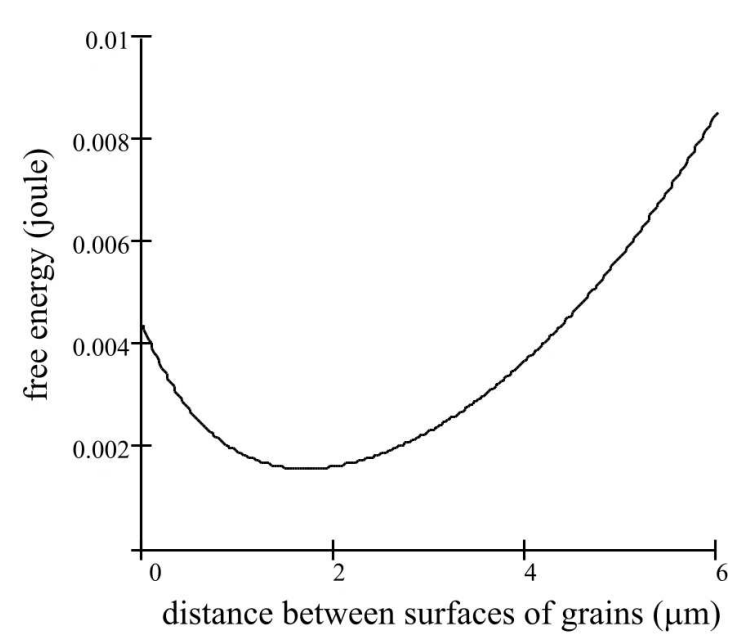

Figure 2. Dependence of a variable part of free energy on the distance among the grains.

Figure 2 shows the dependence of the free energy variable component on the distance between the grains in plasma with the following parameters [3]: the ionizable atom number density is $10^{21} \mathrm{~m}^{-3}$; the number density of the grains is $10^{12} \mathrm{~m}^{-3}$; the radius of the grains is $1 \mu \mathrm{m}$; the temperature is $2300 \mathrm{~K}(0.2 \mathrm{eV})$; the potential of ionization of the atom is $4.3 \mathrm{eV}$.

From the diagram it follows that in the given conditions the equilibrium of the system occurs when the distance among the surfaces of the grains is equal to about 2 microns. It satisfies the micron size grain arrangement, which is shown in figure $1(\mathrm{~b})$.

Thus, the tendency of the grains to agglomerate corresponds to the tendency of dusty plasmas towards the balanced states. We shall emphasize that uncharged grains in the plasma will probably be evenly distributed as they do not import to the plasma the perturbations exceeding the grain size. Agglomeration is caused by forces, rather than by the electrical character due to the strong screening. Probably, the nature of these forces is caused by nonequilibrium ionization near the dust grains $[6,8,12]$. But the keeping of the grains in agglomerate appears to be the superposition of nonelectrical and electrical forces.

\section{References}

1. Chu J.H., I L. // Phys. Rev. Lett., 1994, vol. 72, No. 1, p. 4009-4010.

2. Nefedov A.P., Petrov O.F., Molotkov V.I., Fortov V.E. // JETP Lett., 2000, vol. 72, No. 1, p. 218-219.

3. Dragan G.S., Mal'gota A.A., Protas S.K., Smaglenko T.F., Sokolov Yu.V. Fuel preparation techniques and design of combustors for coal-fired MHD power plants - In: Materials of the scientific and technical meeting of Comecon member countries, Alma-Ata, USSR, 25-31 October 1982, Institute of High Temperatures of the USSR Academy of Sciences (IVTAN), 1984, p. 191-192 (in Russian).

4. Shukla P.K. // Phys. Plasmas, 2001, vol. 8, No. 1, p. 1791-1792.

5. Lampe M., Joyce G., Ganguli G., Gavrishchaka V. // Phys. Plasmas, 2000, vol. 7, No. 1, p. 3851-3852. 
6. Dragan G. Ionization balance displacement gas phase of dusty plasma. - In: V-th European Workshop on Dusty and Colloidal plasmas, Potsdam, Germany, 23-25 August 2001.

7. Dragan G.S., Chesnokov M.N. // Fizika Aerodispersnykh Sistem [Physics of Aero disperse Systems(USSR)], Kiev-Odessa. Vyscha shkola, 1984, vol. 26, p. 57-58 (in Russian).

8. Vishnyakov V.I., Dragan G.S., Margaschuk S.V. Interphase interactions in a lowtemperature plasma. - In: Khimiya Plazmy [Chemistry of Plasmas (USSR)], edited by Smirnov B., Moscow, Energoatomisdat, 1990, vol. 16, p. 98-120 (in Russian).

9. Yakubov I.T., Khrapak A.G. Thermophysical and electrophysical properties of lowtemperature plasma with condensed disperse phase. - In: Sov. Tech. Rev. B. Therm. Phys., 1989, vol. 2, p. 269-337.

10. Fortov V.E., Yakubov I.T. Non-ideal Plasma Physics. Chernogolovka, USSR SA, 1984 (in Russian).

11. Vishnyakov V.I., Dragan G.S., Evtuhov V.M., Margaschuk S.V. // Teplofiz. Vys. Temp. [High Temp.(USSR)], 1987, vol. 25, No. 1, p. 620 (in Russian).

12. Vishnyakov V.I., Dragan G.S. Far interaction of smoke particles in thermal plasmas. - In: 30th EPS Conference on Contr. Fusion and Plasma Phys., St. Petersburg, 2003, ECA, vol. 27A, P-4.119.

13. Bystrenko O., Zagorodny A. // Phys. Rev. E, 2003., vol. 67, p. 066403.

14. Kittel Ch. Thermal Physics. Moscow, Nauka, 1977.

\title{
Термодинамічні причини агломерації пилинок у термічній запорошеній плазмі
}

\author{
В.І.Вишняков, Г.С.Драган \\ Фізичний факультет Одеського національного університету, \\ 65026 Одеса
}

Отримано 21 липня 2003 р.

Вивчається термодинамічна рівновага в термічній запорошеній плазмі, яка містить іонізований газ і тверді частинки (пилинки), що взаємодіють між собою. Тенденція пилинок в запорошеній плазмі до агломерації відповідає тенденції запорошеної плазми до збалансованих станів. У випадку агломерації електричні збурення, породжені кожною пилинкою, зосереджуються всередині агломерату. Тому збурення в плазмі викликані лише зовнішньою поверхнею агломерату. Більшість можливих станів електронів та іонів у плазмі залежить від об'єму, зайнятого пилинками: чим менше збурень, тим більше в плазмі станів, доступних для іонів та електронів. Якщо пилинки зближуються до відстані менше восьми дебаєвських радіусів екранування, сумарний об'єм збурень і вільна енергія плазми мінімізуються.

Ключові слова: плазма, агломерат, термодинаміка, збурення

PACS: $52.27 . L, 52.25 . K$ 